\title{
Kadar Debu terhadap Kapasitas Vital Paru pada Masyarakat di Sekitar PT Semen Baturaja
}

\author{
Sri Indra Tri Gunarso ${ }^{1}$, Prayudhy Yushananta ${ }^{2}$, Fernanda Kurnun Ainin ${ }^{3}$ \\ ${ }^{1,2,3}$ Jurusan Kesehatan Lingkungan, Politeknik Kesehatan Tanjungkarang, Indonesia \\ Email: trigunarsosriindra@gmail.com
}

\begin{abstract}
Dust Levels to Vital Lung Capacity in The Community around PT Semen Baturaja. Function disorders were generally occurred due to individual factors and environmental factors. One of the industries that experienced a lot of development was PT. Semen Batu Raja which is located in Kelurahan Way Lunik. Dust particles with a size of fewer than 50 microns that normally fly can enter the workers' respiratory tract by being sucked in during breathing (ILO, 1998). Public Health Center of Way Lunik mentioned that the prevalence of ARI that occurred during 2016 amounted to 243 cases. The purpose of this study was to determine the relationship of cement dust levels to vital lung capacity in the community around PT. Semen Batu Raja in 2017. The research method was cross-sectional design. Independent variable was humidity of the house, room temperature, ventilation, smoking habits, gender, age, length of stay, and knowledge. While the dependent variable was lung vital capacity. Based on the results of the study, of the 145 Panjang community respondents around PT. Semen Batu Raja obtained 82 respondents who were diagnosed with pulmonary function disorders. Factors that have a significant influence to pulmonary function disorders were ambient dust levels with mean value $171.5 \mu \mathrm{g} / \mathrm{Nm} 3(0.025)$, home ventilation with mean value $\geq 10 \%(0.041)$ and smoking history of respondents with the greatest risk was active smokers. Other factors that were not statistically related were house humidity (0.041) mean $63.2 \%$, house temperature $(0.654)$ mean $29.5^{\circ} \mathrm{C}$, gender, length of stay $(0.82)$, and knowledge $(0.654)$ This study is expected to be reference studies and studies for several parties.
\end{abstract}

Keywords: Dust level, Vital lung capacity

\begin{abstract}
Abstrak: Kadar Debu terhadap Kapasitas Vital Paru pada Masyarakat di Sekitar PT Semen Baturaja. Gangguan fungsi paru pada umumnya terjadi karena faktor individu dan faktor lingkungan. Salah satu industri yang banyak menghasilkan debu adalah industri semen PT. Semen Baturaja yang terletak di Kelurahan Way Lunik, Lampung. Partikel debu dengan ukuran kurang dari 50 mikron yang biasa beterbangan dapat memasuki saluran pernafasan para pekerja dengan cara terisap saat bernafas (ILO,1998). Puskesmas Kelurahan Way Lunik juga menyebutkan bahwa prevalensi penyakit ISPA yang terjadi selama 2016 berjumlah 243 kasus. Tujuan penelitian untuk mengetahui hubungan kadar debu semen terhadap kapasitas vital paru pada masyarakat sekitar PT. Semen Baturaja. Rancangan penelitian cross sectional. Subjek penelitian masyarakat tetap tinggal di sekitar PT. Semen Baturaja. Variabel independen kelembaban rumah, suhu ruangan, ventilasi, kebiasaan merokok, jenis kelamin, usia, lama tinggal, dan pengetahuan. Sedangkan variabel dependennya kapasitas vital paru. Hasil penelitian, dari 145 responden masyarakat Panjang sekitar PT. Semen Baturaja di peroleh 82 responden yang didiagnosis mengalami gangguan fungsi paru. Faktor yang memiliki kemaknaan signifikan terhadap gangguan fungsi paru adalah kadar debu ambien $(0,025)$ mean $171,5 \mu \mathrm{g} / \mathrm{Nm}^{3}$, , ventilasi rumah $(0,041)$ mean $\geq 10 \%$ dan riwayat merokok responden dengan resiko paling besar ialah perokok aktif. Faktor lainnya yang tidak berhubungan secara statistik adalah kelembaban rumah $(0,234)$ mean $63,2 \%$, suhu rumah $(0,616)$ mean $29,5^{\circ} \mathrm{C}$, jenis kelamin $(0,17)$, lama tinggal $(0,82)$, dan pengetahuan $(0,654)$. Penelitian ini diharapkan menjadi referensi studi dan kajian bagi beberapa pihak.
\end{abstract}

Kata kunci: Kadar debu, Kapasitas vital paru

ISPA merupakan infeksi akut yang menyerang salah satu bagian atau lebih dari saluran napas.Pada kondisi dengan komplikasi yang berat, ISPA dapat menyebabkan kematian
(Kemenkes (Dirjen P2PL Kemenkes RI), 2012). Debu merupakan masalah utama penyebab kematian banyak sekali manusia di seluruh dunia. Salah satu industri yang banyak menghasilkan 
debu ialah industri semen. Industri semen merupakan salah satu industri yang perkembangannya sangat pesat di Indonesia, pada periode Januari-Oktober 2015 , penjualan semen Indonesia berada pada 55,9 juta ton, naik $2,1 \%$ dibandingkan penjualan pada periode yang sama tahun sebelumnya ( 54,8 juta ton) (Asosiasi Semen Indonesia, 2016).

Sebuah studi epidemiologi pada sebuah pabrik semen di Dares Salaam Tansania, mengukur tingkat paparan debu dan ditemukan tingkat paparan debu yang tinggi terletak pada cranes $\left(38,64 \mathrm{mgm}^{-3}\right)$, packing $\left(21,30 \mathrm{mgm}^{-3}\right)$. (Mwaiselage.J. Bratveit. M, Moen. B, Mashalla. Y, 2004 ;658-667). Berdasarkan laporan pola penyakit dari Rumah Sakit PT. Semen Tonasa selama 5 tahun (tahun 2000-2004) penyakit saluran pernapasan menduduki peringkat pertama. Periode tahun 2000 persentase penyakit saluran pernapasan $57,3 \%$. Periode tahun 2001 persentase penyakit saluran pernapasan sebanyak $60,6 \%$. Periode 2002 persentase penyakit saluran pernapasan sebanyak 60,4\%. Periode tahun 2003 persentase penyakit saluran pernapasan $49,9 \%$. Periode tahun 2004 persentase penyakit saluran pernapasan sebanyak 47,2\% (Mengkidi, Dorce: 2006).

Di Provinsi Lampung, perusahaan semen yang memiliki perkembangan pesat salah satunya ialah PT. Semen Baturaja yang terletak di Kelurahan Way Lunik, Kecamatan Panjang Utara, Bandar Lampung. PT. Baturaja yang terletak di Panjang ini merupakan perusahaan semen yang bergerak di bidang penggilingan dan pengantongan semen. Oleh karena itu, proses penggilingan dan pengantongan semen di PT. Semen Baturaja masih berkontribusi tinggi pada jumlah debu yang dihasilkan di wilayah Kecamatan Panjang.

Dinas Kesehatan Provinsi Lampung menyebutkan bahwa di daerah Kota Bandar Lampung, angka kesakitan pneumonia pada balita tahun 2015 tertinggi terletak di Puskesmas Panjang yang salah satu wilayah kerjanya ialah Kelurahan Way Lunik. Puskesmas Kelurahan Way Lunik juga menyebutkan bahwa prevalensi penyakit ISPA yang terjadi selama tahun 2016 berjumlah 243 kasus. Berdasarkan uraian yang telah dikemukakan dapat diketahui debu di udara dapat berpengaruh terhadap kesehatan.Tingginya penyakit saluran pernapasan di wilayah kerja Puskesmas yang didalamnya juga merupakan masyarakat yang tinggal di sekitar PT. Semen Baturaja dapat dijadikan sebagai bukti awal adanya gangguan fungsi paru pada masyarakat. Atas dasar itulah perlu dilakukan penelitian dengan judul "Hubungan Kadar Debu Terhadap
Kapasitas Vital Paru Pada Masyarakat di Sekitar PT. Semen Baturaja Tahun 2017”.

Tujuan dalam penelitian ini adalah meengetahui hubungan kadar debu terhadap kapasitas vital paru pada masyarakat di sekitar PT. Semen Baturaja tahun 2017.

\section{METODE}

Dalam penelitian ini menggunakan rancangan penelitian cross sectional yaitu penelitian yang dilakukan dalam satu waktu tertentu dengan satu focus (Neuman, 2003). Variabel terikat dalam penelitian ini adalah kapasitas vital paru. Variabel bebas dalam penelitian ini adalah konsentrasi debu di lingkungan masyarakat. Variabel pengganggu dalam penelitian ini meliputi kelembaban, suhu, ventilasi, kebiasaan merokok, jenis kelamin, lama tinggal dan pengetahuan

Waktu penelitian dilakukan pada minggu kedua Bulan Mei sampai dengan minggu keempat Bulan Juni 2017 dengan lokasi penelitian pada masyarakat Panjang di sekitar PT. Semen Baturaja berfokus di RT. 21, 22, 23, 25, 26, 27, 28, 29, 30, 31, 32 Kelurahan Way Lunik. Populasi pada penelitian ini adalah seluruh rumah tangga Kelurahan Way Lunik di sekitar PT. Semen Baturaja yang bermukim di RT 21, 22, 23, $25,26,27,28,29,30,31,32$ yang berjumlah 1890 orang dan 424 rumah tangga.

Penentuan besar sampel dengan menggunakan rumus sebagai berikut:

$$
\mathrm{n}=\frac{(Z 1-\alpha / 2)^{2} \cdot p \cdot q \cdot N}{d^{2} \cdot(N-1)+(Z 1-\alpha / 2)^{2} \cdot p \cdot q}
$$

Keterangan:

$\mathrm{N}=$ besar sampel (sample size)

$\mathrm{N}=$ besar populasi

$\mathrm{Z} \alpha=$ nilai pada kurva normal untuk $\alpha$ (alpha)

tertentu

$$
\alpha=0,05 \rightarrow Z=1,96
$$

$\mathrm{p}=$ estimator proporsi populasi (angka kejadian penyakit saluran pernapasan masyarakat sekitar PT. Semen Baturaja, Panjang Utara tahun 2016 yang bermukim di RT 21, 22, 23, $25,26,27,28,29,30,31,32$ )

$\mathrm{q}=1-\mathrm{p}$

$\mathrm{d}=$ presisi $=0,1$

Diketahui:

$$
\begin{array}{ll}
\mathrm{N} & =1890 \text { jiwa } \\
\mathrm{p} & =\frac{243}{1890} \times 100 \%=12,8 \%=13 \% \\
\mathrm{q} & =0,87
\end{array}
$$




$$
\begin{aligned}
& \text { Besar Sampel } \\
& =\frac{(1,96)^{2}(0,13)(0,87)(1890)}{0,1^{2} \cdot(1890-1)+(1,96)^{2} \cdot 13 \cdot 0,87} \\
& =\frac{3,84(0,13)(0,87)(1890)}{0,01 \cdot(1889)+(3,84)(0,13)(0,87)} \\
& =\frac{184,145}{4,23+0,44} \\
& =\frac{184,145}{4,67} \\
& =39,43 \rightarrow 40 \text { rumah tangga }
\end{aligned}
$$

$\sim 50$ rumah tangga.

Berdasarkan hasil perhitungan sampel menggunakan rumus cross sectional diatas didapatkan hasil perhitungan sampel sebanyak 40 rumah tangga. Dengan menggunakan rumus yang sama, untuk menghitung jumlah sampel dengan populasi jiwa (presisi 5\%), didapatkan sample sebanyak 159 jiwa. Estimasi jumlah orang dalam 1 rumah tangga berjumlah 4 orang. Agar dapat mewakili populasi jiwa dan rumah tangga maka sampel yang digunakan sebanyak 50 rumah tangga. Sampling dilakukan dengan menggunakan salah satu teknik sampling, yaitu menggunakan undian.

\section{HASIL}

\section{Gambaran Variabel Penelitian}

Hasil penelitian menunjukkan bahwa sebanyak 56,6\% responden memiliki gangguan pada kapasitas vital paru, sedangkan $43,4 \%$ lainya memiliki kapasitas vital paru normal. Kapasitas vital paru dikatakan mengalami gangguan ketika pada saat pemeriksaan dengan menggunakan spiro ball, jumlah bola yang terangkat $\leq 1$ bola. Hasil penelitian juga menunjukkan terdapat 1 titik yang hasil pengukuranya di bawah BML (MS), yaitu pada pengukuran kedua dan merupakan titik lokasi di RT 21-23 Kelurahan Way Lunik. Terdapat 58,5\% responden tinggal di rumah yang kelembabanya tidak memenuhi syarat, sedangkan $41,4 \%$ responden lainya memenuhi syarat. Rata-rata hasil pengukuran kelembaban udara yaitu 63,2. Kelembaban udara 55\% mengalami frekuensi tertinggi yaitu 20. Kelembaban minimum pada pengukuran ini ialah $49 \%$ dan maximum $75 \%$. Sebanyak 57,9\% responden tinggal di rumah dengan suhu memenuhi syarat, sedangkan $42,1 \%$ responden lainya tidak memenuhi syarat. Sebanyak 40,7\% responden memiliki rumah dengan ventilasi memenuhi syarat, sedangkan $59,3 \%$ responden lainya tidak memenuhi syarat. Hasil penelitian juga menjelaskan kebanyakan responden bukanlah perokok yang ditunjukkan dengan persentase sebesar 68,3\%. Responden paling banyak berjenis kelamin perempuan dengan persentase $63,4 \%$. Sedangkan persentase responden dengan jenis kelamin laki-laki yaitu $36,6 \%$. Distribusi responden yang tinggal $\geq 10$ tahun di sekitar PT. Semen Baturaja lebih banyak dibandingkan dengan responden yang tinggal $<10$ tahun, dengan persentase sebesar $84,8 \%$. Hasil penelitian juga menunjukkan bahwa sebanyak $84,1 \%$ tingkat pengetahuan responden dikategorikan tidak baik, sedangkan 15,9\% lainya

\begin{tabular}{|c|c|c|c|}
\hline Variabel & Hasil Ukur & n & $\%$ \\
\hline \multirow{2}{*}{$\begin{array}{l}\text { Kapasitas Vital } \\
\text { Paru Responden }\end{array}$} & Ada Gangguan & 82 & 56,6 \\
\hline & Normal & 63 & 43,4 \\
\hline \multirow{2}{*}{$\begin{array}{l}\text { Kadar Debu } \\
\text { Ambien }\end{array}$} & TMS & 106 & 73,1 \\
\hline & MS & 39 & 26,9 \\
\hline \multirow{2}{*}{$\begin{array}{l}\text { Kelembaban } \\
\text { Rumah }\end{array}$} & TMS & 85 & 58,5 \\
\hline & MS & 60 & 41,4 \\
\hline \multirow[t]{2}{*}{ Suhu Ruangan } & $\begin{array}{l}\text { Tidak Memenuhi } \\
\text { Syarat }\end{array}$ & 61 & 42,1 \\
\hline & Memenuhi Syarat & 84 & 57,9 \\
\hline \multirow[t]{2}{*}{ Ventilasi Rumah } & $\begin{array}{l}\text { Tidak Memenuhi } \\
\text { Syarat }\end{array}$ & 86 & 59,3 \\
\hline & Memenuhi Syarat & 59 & 40,7 \\
\hline \multirow{2}{*}{$\begin{array}{l}\text { Riwayat } \\
\text { Merokok }\end{array}$} & Perokok & 46 & 31,7 \\
\hline & Bukan Perokok & 99 & 68,3 \\
\hline \multirow[t]{2}{*}{ Jenis Kelamin } & Laki-Laki & 53 & 36,6 \\
\hline & Perempuan & 92 & 63,4 \\
\hline \multirow[t]{2}{*}{ Lama Tinggal } & $\geq 10$ tahun & 123 & 84,8 \\
\hline & $<10$ tahun & 22 & 15,2 \\
\hline \multirow{2}{*}{$\begin{array}{l}\text { Tingkat } \\
\text { Pengetahuan }\end{array}$} & Tidak Baik & 122 & 84,1 \\
\hline & Baik & 23 & 15,9 \\
\hline
\end{tabular}
masuk kedalam kategori sudah baik. Tabel hasil penelitian mengenai gambaran masing-masing variabel ini secara sederhana dapat disajikan sebagai berikut:

\section{Tabel 1. Gambaran Masing-Masing Variabel}

\section{Hubungan Variabel Penelitian dengan Kapasitas Vital Paru}

Hasil uji chi-square $\left(x^{2}\right)$ yang dilakukan pada analisis kadar debu menunjukkan terdapat hubungan yang bermakna antara kadar debu ambien dengan kapasitas vital paru responden. Nilai OR menunjukkan hasil 2,37 artinya responden yang tinggal di area dengan kadar debu TMS memiliki 2,37 kali resiko lebih besar memiliki gangguan kapasitas vital paru dibandingkan dengan responden yang tinggal di area dengan kadar debu MS. Pada analisis kelembaban rumah, tidak terdapat hubungan yang bermakna antara kelembaban rumah dengan kapasitas vital paru responden. Nilai $\mathrm{OR}=1,576$; 95\% CI $=0,80-3,0$. Terdapat hubungan yang bermakna antara ventilasi rumah dengan kapasitas vital paru responden. Nilai OR 
menunjukkan hasil 2,1 (95\%CI:1,07-4,13). Terdapat hubungan yang bermakna antara riwayat merokok dengan kapasitas vital paru responden. Nilai OR menunjukkan hasil 9,05 artinya responden yang merupakan responden dengan kategori perokok beresiko 9,05 kali lebih besar mengalami gangguan fungsi paru dibandingkan responden yang bukan perokok. Pada penelitian ini, hasil uji chi-square $\left(x^{2}\right)$ yang diperoleh menunjukkan tidak terdapat hubungan antara jenis kelamin dengan kapasitas vital paru responden. Tidak terdapatnya hubungan antara lama tinggal dengan kapasitas vital paru responden. Dari hasil analisis juga di peroleh nilai $\mathrm{OR}=0,88 ; 95 \% \mathrm{CI}=0,35-2,22$. Dan juga, tidak terdapat hubungan antara tingkat pengetahuan dengan kapasitas vital paru responden pada penelitian ini dan di peroleh nilai $\mathrm{OR}=1,234 ; 95 \% \mathrm{CI}=0,505-3,015$.

\section{Nilai Risiko Kapasitas Vital Paru Berdasarkan Variabel Counfounding}

Uji stratifikasi dilakukan untuk mengetahui pengaruh hubungan kadar debu terhadap kejadian kapasitas vital paru pada penelitian ini setelah dikendalikan oleh variabel confounding. Berdasarkan hasil uji stratifikasi, variabel yang berperan sebagai variabel confounding ialah variabel kelembaban, suhu, ventilasi, riwayat merokok, lama tinggal dan pengetahuan. Sedangkan jenis kelamin bukan merupakan variabel counounding pada penelitian ini.

Tabel 2. Hasil Uji Stratifikasi Variabel Confounding terhadap Hubungan Kadar Debu dengan Kejadian Kapasitas Vital Paru

\begin{tabular}{|c|c|c|c|c|c|c|}
\hline \multicolumn{2}{|c|}{ Variabel } & \multirow{2}{*}{$\begin{array}{r}\text { OR Strata } \\
2,08\end{array}$} & \multirow{2}{*}{$\frac{p \text {-value }}{0,26}$} & \multirow{3}{*}{$\begin{array}{c}\begin{array}{c}\text { Crude } \\
\text { OR }\end{array} \\
2,37\end{array}$} & \multirow{3}{*}{$\begin{array}{c}\text { Adj } \mathbf{~ O R} \\
2,27\end{array}$} & \multirow{3}{*}{$\begin{array}{c}\text { Status Variabel } \\
\text { Confounding }\end{array}$} \\
\hline & TMS & & & & & \\
\hline Kelembaban & MS & 2,51 & 1,17 & & & \\
\hline \multirow{2}{*}{ Suhu } & TMS & 1,48 & 0,67 & \multirow{2}{*}{2,37} & \multirow{2}{*}{2,32} & \multirow{2}{*}{ Confounding } \\
\hline & MS & 3,54 & 0,03 & & & \\
\hline \multirow{2}{*}{ Ventilasi } & TMS & 1,39 & 0,79 & \multirow{2}{*}{2,37} & \multirow{2}{*}{1,93} & \multirow{2}{*}{ Confounding } \\
\hline & MS & 2,57 & 0,15 & & & \\
\hline \multirow{2}{*}{$\begin{array}{l}\text { Riwayat } \\
\text { merokok }\end{array}$} & Perokok & 1,8 & 0,52 & \multirow{2}{*}{2,37} & \multirow{2}{*}{1,59} & \multirow{2}{*}{ Confounding } \\
\hline & Bukan Perokok & 1,1 & 0,39 & & & \\
\hline \multirow{2}{*}{ Jenis Kelamin } & Perempuan & 2,48 & 0,09 & \multirow{2}{*}{2,37} & \multirow{2}{*}{2,39} & \multirow{2}{*}{$\begin{array}{c}\text { Bukan } \\
\text { Confounding }\end{array}$} \\
\hline & Laki-laki & 2,25 & 0,20 & & & \\
\hline \multirow{2}{*}{ Lama Tinggal } & $\geq 10$ tahun & 2,50 & 0,04 & \multirow{2}{*}{2,37} & \multirow{2}{*}{2,36} & \multirow{2}{*}{ Confounding } \\
\hline & $<10$ tahun & 1,57 & 1,00 & & & \\
\hline \multirow{2}{*}{ Pengetahuan } & Tidak Baik & 2,56 & 0,45 & \multirow{2}{*}{2,37} & \multirow{2}{*}{2,35} & \multirow{2}{*}{ Confounding } \\
\hline & Baik & 1,67 & 0,87 & & & \\
\hline
\end{tabular}

\section{PEMBAHASAN}

Tingginya kadar debu di suatu tempat dapat mengindikasikan pencemaran udara. Debu yang dihasilkan pada lokasi penelitian berasal dari industri dan kendaraan dari jalan lalu lintas yang padat dan sangat dipengaruhi oleh arah angin di area sekitar PT. Semen Baturaja.

Seperti telah dipaparkan pada gambaran umum lokasi penelitian, bahwa lokasi penelitian ini diapit oleh 2 jalan besar dan merupakan jalan dengan kepadatan lalu lintas yang cukup tinggi. Dengan kepadatan unit kendaraan yang sangat tinggi menganalogikan bahwa kadar debu dijalan tersebut juga tinggi, hal ini sesuai dengan penelitian yang dilakukan oleh Hapsari (2008), bahwa tingginya kadar debu di sekitar pos penjagaan polisi Semarang Timur lebih tinggi ketika terjadi kemacetan lalu lintas dibandingkan dengan kadar debu dalam keadaan lalu lintas lancar tanpa kemacetan. Selain debu yang dihasilkan secara alami, juga berasal dari sisa pembakaran kendaraan bermotor, terutama yang berbahan bakar solar. Pope III et al. (2006) dalam Fathmaulida, Annisa (2013), partikel PM $_{10}$ yang berdiameter 10 mikron memiliki tingkat kelolosan yang tinggi dari saringan pernafasan manusia dan bertahan di udara dalam waktu cukup lama. Tingkat bahaya semakin meningkat pada pagi dan malam hari karena asap bercampur dengan uap air. $\mathrm{PM}_{10}$ tidak terdeteksi oleh bulu hidung sehingga masuk ke paru-paru. Jika partikel tersebut terdeposit ke paru-paru akan menimbulkan peradangan saluran pernafasan.

Kelembaban udara adalah kandungan uap air yang ada di udara. Berdasarkan hasil penelitian didapatkan rata-rata kecepatan angin sebesar $0,47 \mathrm{~m} /$ detik dan angin bergerak ke arah timur. Jika dibandingkan dengan teori yang ada, kecepatan angin di daerah penelitian ini masuk ke 
dalam kategori sepoi-sepoi yang bertemperatur kering. Pengaruh kelembaban terhadap debu dapat terjadi karena debu memiliki kemampuan absorbsi uap air yang ada di sekitarnya sehingga berat molekulnya bertambah dan memperkecil kemungkinan dispersi.

Suhu atau Temperatur udara antara suatu daerah dengan daerah lainnya sangat berbeda. Perbedaaan ini disebabkan adanya beberapa faktor, seperti sudut datang sinar matahari, ketinggian suatu tempat, arah angin, arus laut, awan, dan lamanya penyinaran. Semakin tinggi suhu lingkungan, tubuh manusia akan semakin berkeringat untuk mempertahankan suhu tubuhnya. Widiyananto (2014) mengatakan manusia memiliki temperatur tubuh sekitar $37^{\circ} \mathrm{C}$. Temperatur tersebut diradiasikan oleh tubuh.Untuk mempertahankan temperatur maka tubuh melakukan transpirasi atau evaporasi atau mengeluarkan keringat. Panas yang dihasilkan oleh tubuh manusia harus segera dilepas, hal ini bisa kita ketahui bila kita berkeringat sebagai tanda bahwa mekanisme tubuh kita bekerja. Kemampuan individu untuk beradaptasi dengan lingkungan sekitarnya berbeda antara individu satu dengan yang lainnya, saat beraktifitas dengan suhu yang tinggi, tubuh akan mengalami kehilangan banyak cairan. Pada kondisi ini tubuh akan melakukan mekanisme fisiologis dengan mengeluarkan panas untuk menstabilkan suhu inti tubuh. Pengaruh udara panas yang berlebih terhadap tubuh dapat menyebabkan terjadinya kram panas (heatcramps), serangan panas secara tiba-tiba (heat syncope, heat stroke) (Novita, 2007).

Ventilasi adalah proses penyediaan udara segarke dalam dan pengeluaran udara kotor dari suatu ruangan tertutup secara alamiah maupun mekanis. Pertukaran udara yang tidak memenuhi syarat dapat menyebabkan suburnya pertumbuhan mikroorganisme, yang mengakibatkan gangguan terhadap kesehatan manusia khususnya saluran pernapasan. Terdapatnya bakteri di udara disebabkan adanya debu dan uap air. Jumlah bakteri udara akan bertambah jika penghuni ada yang menderita penyakit saluran pernapasan, seperti TBC, Influenza, dan ISPA. Standar luas ventilasi rumah, menurut Kepmenkes RI No.829 tahun 1999, adalah minimal 10\% luas lantai.
Menurut Ikhwan (2009) dalam

Fathmaulida (2013) kebiasaan merokok dapat mempengaruhi kapasitas vital paru. Saat merokok terjadi suatu proses pembakaran tembakau dengan mengeluarkan polutan partikel padat dan gas. Asap rokok akan merangsang sekresi lendir sedangkan nikotin akan melumpuhkan silia sehingga fungsi pembersihan jalan napas terhambat dan konsekuensinya terjadi penumpukan sekresi lendir yang menyebabkan terjadinya batuk-batuk, banyak dahak dan sesak napas. Gejala tersebut dapat disebabkan karena paparan partikel dan gas pembakaran tembakau tersebut. Merokok dapat memicu terjadinya bronkitis kronis karena adanya iritasi kronis pada selaput lendir (mukosa) saluran nafas. Selanjutnya terjadi hipertrofi selaput lendir dan hipersekresi lendir (mukus). Lingkungan yang terpapar oleh debu serta ditambah dengan kebiasaan merokok dapat memberikan dampak kumulatif terhadap timbulnya gangguan kesehatan paru karena asap rokok dapat menghilangkan bulu-bulu silia di saluran pernafasan yang berfungsi sebagai penyaring udara yang masuk ke hidung sehinga mekanisme pengeluaran debu oleh paru dapat terganggu (Faidawati, 2003).

Berdasarkan hasil analisis yang di dapatkan dari hasil penelitian pada variabel jenis kelamin, diperoleh kelompok usia paling banyak mengalami gangguan fungsi paru ialah kelompok usia 17-25 tahun dengan persentase 20,5\% lakilaki dan $79,5 \%$ perempuan. Pada kelompok usia 17-25, pekerjaan responden mayoritas ialah pelajar. Dengan demikian, Peneliti berasumsi jika pada penelitian ini, hasil menunjukkan bahwa laki-laki lebih dominan mengalami gangguan fungsi paru disebabkan karena paparan debu yang terhirup oleh pelajar ini lebih banyak dibandingkan dengan masyarakat yang hanya tinggal di dalam rumah. Seperti telah dijelaskan sebelumnya bahwa Kelurahan Way Lunik ini terletak di dua jalan besar dengan kepadatan lalu lintas yang cukup tinggi, ditambah terletak di kawasan industri yang salah satu industrinya berperan besar dalam menyumbangkan debu ambien, industri tersebut ialah PT. Semen Baturaja.

Lama tinggal pada penelitian ini merupakan salah satu cara untuk mengetahui lama paparan responden terpapar oleh debu. Hal ini diperlukan karena lama paparan merupakan salah satu faktor yang berpengaruh pada timbulnya gangguan pernafasan. Morgan dan Parkes dalam Faidawati (2003) menyebutkan bahwa waktu yang dibutuhkan seseorang terpapar oleh debu untuk terjadinya fungsi paru lebih dari 10 tahun. Kemudian, penelitian Sumanto (1999) dalam Fathmaulida (2013) menunjukkan bahwa semakin lama seseorang bekerja pada lingkungan berdebu, maka dapat menurunkan kapasitas vital paru. Lama paparan ini juga dipengaruhi oleh pekerjaan responden. semakin jauh dan semakin lama responden berada diluar daerah penelitian, 
maka semakin berkurang pula waktu paparan responden. Pada hasil analisis distribusi dan frekuensi mengenai pekerjaan, pekerjaan yang paling banyak dimiliki oleh responden ialah lainya, dengan persentase $29,7 \%$. Lainnya yang dimaksud disini ialah pekerjaan seperti ibu rumah tangga, PSK dan beberapa pekerjaan yang tidak ada di pilihan. Persentase pekerjaan terbanyak selanjutnya ialah pelajar, yaitu sebanyak $24,1 \%$. Berdasarkan hasil wawancara peneliti dengan responden yang pekerjaanya ialah pelajar menyebutkan bahwa mereka bersekolah di luar Kecamatan Panjang, dimana jarak antara sekolah dengan wilayah sekitar penelitian mencapai lebih dari 10m. Mengkidi (2006) menjelaskan, lama paparan berkaitan dengan jumlah jam kerja yang dihabiskan masyarakat di area kerja. Semakin lama masyarakat menghabiskan waktu untuk bekerja di area kerjanya, semakin lama pula paparan debu yang diterimanya, sehingga untuk terjadinya gangguan fungsi paru (KVP di bawah normal) juga akan semakin besar, tetapi hal itu juga tergantung dari konsentrasi debu yang ada di area kerja dan mekanisme clearance dari masingmasing individu, kadar partikel debu dan kerentanan individu.

Kurangnya tingkat pengetahuan masyarakat Panjang di sekitar PT. Semen Baturaja terhadap bahaya debu semen ini dapat dipengaruhi oleh beberapa faktor. Tingkat pendidikan seseorang akan berpengaruh dalam memberi respon yang dating dari luar. Orang yang berpendidikan tinggi akan memberikan respon yang lebih rasional terhadap informasi dan akan berpikir sejauh mana keuntungan yang mungkin akan mereka peroleh dari gagasan tersebut. Dari uraian di atas, diketahui bahwa kemampuan seseorang dalam menerima dan mengolah informasi agar menjadi pengetahuan yang baik berbeda-beda.

\section{SIMPULAN}

Berdasarkan hasil penelitian pada masyarakat Panjang di sekitar PT. Semen Baturaja, maka didapatkan kesimpulan bahwa Hubungan mengenai masing-masing variabel dengan kejadian kapasitas vital paru dapat disimpulkan sebagai berikut:
1. Terdapat hubungan yang bermakna antara kadar debu ambien dengan kapasitas vital paru responden dengan $p$-value $=0,036$.

2. Tidak terdapat hubungan yang bermakna antara kelembaban rumah dengan kapasitas vital paru responden dengan $p$-value $=0,243$.

3. Tidak terdapat hubungan yang bermakna antara suhu rumah dengan kapasitas vital paru responden, dengan $p$-value $=0,735$.

4. Terdapat hubungan yang bermakna antara ventilasi rumah dengan kapasitas vital paru responden $p$-value $=0,045$.

5. Terdapat hubungan yang bermakna antara riwayat merokok dengan kapasitas vital paru responden. Responden yang merupakan perokok aktif memiliki resiko 3,12 kali lebih besar mengalami gangguan fungsi paru dibandingkan responden yang bukan perokok.

6. Tidak terdapat hubungan antara jenis kelamin dengan kapasitas vital paru responden, $p$-value $=0,17$.

7. Tidak terdapatnya hubungan antara lama tinggal dengan kapasitas vital paru responden, $p$-value $=0,82$.

8. Tidak terdapat hubungan antara tingkat pengetahuan dengan kapasitas vital paru responden, $p$-value $=0,654$.

9. Dari ketiga variabel yang memiliki hubungan bermakna dengan kapasitas vital paru responden, kelembaban merupakan variabel confounding $(\mathrm{OR}=2,27)$, sedangkan ventilasi dan riwayat merokok merupakan variabel confounding interval, OR ventilasi $\mathrm{TMS}=1,39$ dan $\mathrm{OR}$ ventilasi $\mathrm{MS}=2,57$. Sedangkan OR untuk perokok $=1,73$, OR mantan perokok $=0,00$ dan OR bukan perokok=3,04.

\section{SARAN}

Penelitian ini diharapkan dapat menjadi acuan atau referensi bagi penelitian selanjutnya, untuk dapat dikembangkan lebih baik lagi, dan diaplikasikan oleh beberapa pihak terkait. 


\section{DAFTAR PUSTAKA}

Asosiasi Semen Indonesia. 2016. Perkembangan Industri Semen di Indonesia, Periode Januari-Oktober 2015. Berita online, http://www.indonesiainvestments.com/id/berita/berita-hariini/industri-semen-indonesia-tahun-2016pertumbuhan-karena-doronganinfrastruktur/item6331?

Dinas Kesehatan Provinsi Lampung. 2015. Profii Kesehatan Provinsi Lampung Tahun 2015. Bandar Lampung.

Faidawati, R. 2003. Penyakit Paru Obstruktif Kronik Dan Asma Akibat Kerja. Journal of the Indonesia Association of Pulmonologist. Jakarta.

Fathmaulida, Annisa. 2013. Faktor-Faktor yang Berhubungan dengan Gangguan Fungsi Paru Pada Pekerja Pengolahan Batu Kapur Di Desa Tamansari Kabupaten Karawang Tahun 2013. [Skripsi]. Jakarta: Fakultas Kedokteran dan Ilmu Kesehatan, Universitas Islam Negeri Syarif Hidayatullah.

Hapsari, Melati Indri. 2008. Hubungan Kualitas Udara Ambien (Kadar Debu, NOx dan SOx) dengan Kejadian Gangguan Fungsi Paru Pada Polisi Lalu Lintas di Kesatuan Lalu Lintas Polres Semarang Timur. [Tesis]. Semarang: Magister Kesehatan Lingkunga, Universitas Diponegoro.

Kementerian Kesehatan Republik Indonesia. 1999. Keputusan Menteri Kesehatan No. 829 Tahun 1999 Tentang: Persyaratan
Kesehatan Perumahan. Jakarta.

Kementerian Kesehatan Republik Indonesia. 2012. Pedoman Pengendalian Infeksi Saluran Pernafasan Akut. Direktorat Jenderal Pengendalan Penyakit dan Penyehatan Lingkungan.

Mengkidi, Dorce. 2006. Gangguan Fungsi Paru dan Faktor-Faktor yang Mempengaruhi Pada Karyawan PT. Semen Tonasa Pangkep Sulawesi Selatan. [Tesis]. Semarang: Magister Kesehatan Lingkungan, Konsentrasi Kesehatan Lingkungan Industri, Universitas Diponegoro.

Mwaiselage, J., Bråtveit, M., Moen, B., \& Mashalla, Y. 2004. Cement dust exposure and ventilatory function impairment: an exposure-response study. Journal of occupational and environmental medicine, 46(7), 658-667.

Novita, E. 2007. Adaptasi Fisiologis Terhadap Latihan di Suhu Lingkungan Panas Dan Dingin. Poperti UNY.

PT. Semen Baturaja. 2017. Profil Perusahaan PT. Semen Baturaja Bandar Lampung Provinsi Lampung. (https://m2indonesia.com/informasi/perus ahaan/profil-perusahaan-semen-baturajapt-bandar-lampung-provinsilampung.htm).

Widiyananto, E. 2014. Tinjauan Fisika Bangunan Penyebab Perasaan Gerah Manusia pada Sebuah Ruang. 